\title{
Professional driving, smoking, and lung cancer: a case referent study
}

\author{
L DAMBER AND L G LARSSON
}

From the Centre of Oncology, University Hospital, S-901 85 Umea, Sweden

ABSTRACT In a case referent study of about 600 cases of male lung cancer in northern Sweden the risk in professional drivers was specifically studied. Data concerning occupations, time and type of employment, and smoking habits were collected by questionnaires directed to close relatives. On average, professional drivers were heavier smokers and this was the chief cause of a slightly increased crude risk ratio in the study as a whole. Smoking drivers in an upper age group ( 70 and over) had a high relative risk of lung cancer, whereas in a lower age group (under 70) no significant increase was found. The relative risk in non-smoking drivers in the upper age group $t$ was moderately raised with borderline statistical significance. The high relative risk estimated for smoking drivers in the upper age group suggests a synergistic effect between smoking and occupational exposure.

Combustion of fossil fuels produces small amounts of benzo(a)pyrene (B(a)P) and other polycyclic aromatic hydrocarbons (PAH), the mutagenic and carcinogenic effects of which have been well documented through experimental studies.' Epidemiological evidence that these products cause lung cancer in man has been obtained from studies on gas workers, coke oven workers, and asphalt workers..$^{2-4}$

In many industrialised countries the incidence rate of lung cancer is higher in urban areas, especially in large metropolitan regions, than in rural areas. It is suspected that general air pollution is partly responsible for these differences but its quantitative importance is largely unknown. The higher urban lung cancer rates are certainly also due to other factors such as differences in smoking habits and occupational exposure. In most studies dealing with air pollution information about these factors, however, is missing. In two studies where an account was taken of both smoking habits and risk occupations the risk due to general air pollution per se was found to be minimal. ${ }^{56}$ One of these studies, however, suggested a synergistic interaction between smoking and air pollution. ${ }^{5}$

In international concensus reports it has been assessed that general air pollution from the combustion of fossil fuels, probably in interaction with cigarette smóking, causes five to 10 cases of lung cancer a year among 100000 men in large urban Received 21 May 1984 Accepted 2 July 1984 regions. ${ }^{7}$ This assessment, however, is uncertain and mainly based on extrapolation from experimental data and epidemiological data obtained for specific occupation.

Through the exhaust of diesel and gasoline engines, professional drivers are exposed to $\mathrm{B}(\mathrm{a}) \mathrm{P}$ and other carcinogenic $\mathrm{PAH}^{8}{ }^{8}$ In their vehicles diesel engines are much more frequent than gasoline engines and may emit ten times as much B(a)P.9 Few epidemiological studies, however, have been designed to examine the possible increased risk of lung cancer in this occupation. Some studies based on registers have shown an overrepresentation of professional drivers among cases of lung cancer. ${ }^{10-14}$ On the other hand, negative studies have also been 3 published, such as the cohort analysis of London Transport employees; an increased mortality rate from lung cancer among drivers was not 0 observed. ${ }^{1516}$ The incidence of lung cancer among professional drivers in Sweden was studied using a special register (the Cancer-Environment Register, CMR) obtained by record linkage between the $O$ Swedish Cancer Register and a census containing $N$ information about occupation. Compared with a N reference population, professional drivers were $\omega$ overrepresented among cases of lung cancer. From these data a relative lung cancer risk in drivers of $\stackrel{\varrho}{\subset}$ 1.33 was estimated for the whole of Sweden and of 1.62 for the city of Stockholm. ${ }^{17}$ In a large group of Swedish stevedores exposed to diesel exhaust a slightly increased mortality rate from lung cancer (SMR 132) was found. ${ }^{18}$ In none of the cited studies 
on transport workers were smoking habits taken into account. Furthermore, detailed data concerning time and duration of employment were lacking in most investigations.

The present report is part of a large case referent study of lung cancer in men with emphasis on occupational exposure and smoking. The general outline of this study has already been reported in articles on lung cancer in miners. ${ }^{1920}$ For the present report, the case referent material was specifically used to elucidate risks of lung cancer in professional drivers. The study was performed in the most northern part of Sweden. This may be of special interest, as the air in vehicle cabins may contain high concentrations of combustion products during the winter. ${ }^{21}$

\section{Material and methods}

The whole case referent study comprised 604 male patients with lung cancer from the three most northern counties in Sweden. The study included all new cases reported to the Swedish Cancer Registry in 1972-7 who had died at least one year before the start of the study (May 1979). All the cytological and histopathological reports of the cases were collected and reviewed, thus allowing the cases to be classified according to cell type. To each case, a deceased referent was drawn from the National Registry for Causes of Death, matched according to sex, year of death, age, and municipality. Lung cancer cases and suicides were not accepted as referents. Since smoking is related also to causes of death other than lung cancer, a living referent was also included for each case. These referents were taken from the National Population Registry and matched against the cases according to sex, year of birth, and municipality. Only living referents with an age not exceeding 80 (467 referents), however, were drawn in order not to disturb very old people with questionnaires. The study thus included 467 cases all born in 1900 or later with two referents (one deceased and one living) and 137 cases born before 1900 with only one referent (deceased). The analyses in this report are mainly based on the 467 cases with two referents (tables $1-7$ and 10, figure). Corresponding analyses were also made for all the cases, each with one referent (deceased), but they gave essentially similar results and are therefore not reported. The only exceptions are in tables 8 and 9, in which all the cases were used in order to elucidate better the risks in the upper age group.

Through questionnaires data were collected concerning municipality, type of residence, occupation and employment, and smoking habits. The questionnaires were answered by the next of kin of the cases and of the deceased referents, and by the living referents themselves. Incomplete answers were supplemented by telephone interviews according to defined control criteria. Between $95 \%$ and $97 \%$ of the questionnaires were answered in the three groups.

Data concerning smoking habits included the approximate year of starting to smoke, the daily number of cigarettes, and the year of possible cessation of smoking. People who had smoked at least one cigarette daily for one year or more at any time were classified as smokers. From the smoking data, the lifetime consumption of tobacco was estimated and expressed as numbers of cigarettes. For pipe and cigar smoking, $1 \mathrm{~g}$ tobacco was regarded as equal to one cigarette. It was possible to obtain information about occupations and employment for an average of 38.9 years for the cases, 38.4 years for the deceased referents, and $38 \cdot 1$ years for the living referents. The questionnaires gave information about the type of professional driving (taxi, bus, truck, or van). All individuals who had been active in the profession for at least one year were classified as professional drivers. The only measure of exposure used in this study was occupation-year.

\section{STATISTICAL METHODS}

The relative risk (odds ratio) of lung cancer for professional drivers estimated with individual matching $^{22}$ was $1 \cdot 31$, and after dissolving the matching, 1.36. The correlation of exposure (professional driving) between cases and their matched control was $-0 \cdot 04$. This low correlation coefficient and the similarity between the two risk estimates indicated that matching could be ignored in the analyses. Confidence intervals were estimated according to Miettinen. ${ }^{23}$ For small subgroups, the confidence limit was obtained using the exact procedure based on Fisher's exact test. ${ }^{24}$ The homogeneity of the odds ratio was tested with an asymptotic likelihood ratio test ( $\mathrm{O}$ Miettinen, unpublished data). To determine the interrelation between the risk factors an index of synergy was estimated based on principles described by Rothman. ${ }^{25}$

\section{Results}

In the group of cases there were relatively more drivers and driver-years than in the group of referents (table 1). When the drivers were divided into different subgroups, only occupation years as truck drivers were overrepresented among the cases compared with the referents. The further analyses were performed on truck drivers as a subgroup and professional drivers in general. The drivers, both among the cases and the referents, had an average time in the occupation of about 20 years (table 1 ). 
Table 1 Professional driving among cases and referents

\begin{tabular}{|c|c|c|c|c|c|c|}
\hline & \multicolumn{2}{|c|}{ Professional driving } & \multicolumn{2}{|c|}{ Truck driving } & \multicolumn{2}{|c|}{$\begin{array}{l}\text { Bus, taxi, and van } \\
\text { driving }\end{array}$} \\
\hline & Cases & Referents & Cases & Referents & Cases & Referents \\
\hline $\begin{array}{l}\text { No } \\
\text { Driver-years } \\
\text { Driver-years, average among all cases } \\
\text { and referents }\end{array}$ & $\begin{array}{c}63 \\
1296 \\
2 \cdot 8\end{array}$ & $\begin{array}{r}95 \\
1867 \\
2 \cdot 1\end{array}$ & $\begin{array}{c}35 \\
812 \\
1.8\end{array}$ & $\begin{array}{c}57 \\
953 \\
1 \cdot 1\end{array}$ & $\begin{array}{c}26 \\
408 \\
0.9\end{array}$ & $\begin{array}{c}37 \\
751 \\
0.8\end{array}$ \\
\hline Driver-years, average among drivers & $20 \cdot 6$ & $19 \cdot 7$ & $23 \cdot 2$ & $16 \cdot 7$ & $15 \cdot 7$ & $20 \cdot 3$ \\
\hline
\end{tabular}

Table 2 Lung cancer in professional drivers in general and in truck drivers according to time in occupation. Odds ratios

\begin{tabular}{|c|c|c|c|c|}
\hline & Cases & Referents & $\begin{array}{l}\text { OR without adjustment } \\
\text { to age }\end{array}$ & $95 \%$ Conf interval \\
\hline Non-drivers & 393 & 804 & $(1 \cdot 0)$ & \\
\hline $\begin{array}{l}\text { Drivers: } \\
>1 \text { year } \\
>10 \text { year } \\
>20 \text { year } \\
\text { Truck drivers: }\end{array}$ & $\begin{array}{l}63 \\
43 \\
33\end{array}$ & $\begin{array}{l}95 \\
60 \\
42\end{array}$ & $\begin{array}{l}1 \cdot 36 \\
1 \cdot 47 \\
1 \cdot 61\end{array}$ & $\begin{array}{l}0.97-1.91 \\
0.97-2 \cdot 20 \\
1 \cdot 01-2.57\end{array}$ \\
\hline $\begin{array}{l}\text { Truck drivers: } \\
>1 \text { year } \\
>10 \text { year } \\
>20 \text { year }\end{array}$ & $\begin{array}{l}35 \\
26 \\
20\end{array}$ & $\begin{array}{l}57 \\
32 \\
24\end{array}$ & $\begin{array}{l}1 \cdot 26 \\
1 \cdot 66 \\
1 \cdot 70\end{array}$ & $\begin{array}{l}0.81-1.95 \\
0.98-2.81 \\
0.94-3.10\end{array}$ \\
\hline
\end{tabular}

Table 3 Professional driving among cases and referents stratified by age

\begin{tabular}{|c|c|c|c|c|}
\hline $\begin{array}{l}\text { Age at diagnosis } \\
\text { (years) }\end{array}$ & $C / R$ & Drivers & Non-drivers & $O R$ \\
\hline$<60$ & $\begin{array}{l}\mathbf{C} \\
\mathrm{R}\end{array}$ & $\begin{array}{l}24 \\
37\end{array}$ & $\begin{array}{r}94 \\
192\end{array}$ & $1 \cdot 33$ \\
\hline $60-69$ & $\begin{array}{l}\mathbf{C} \\
\mathrm{R}\end{array}$ & $\begin{array}{l}16 \\
42\end{array}$ & $\begin{array}{l}165 \\
318\end{array}$ & 0.73 \\
\hline$\geqslant 70$ & $\begin{array}{l}\mathbf{C} \\
\mathbf{R}\end{array}$ & $\begin{array}{l}23 \\
16\end{array}$ & $\begin{array}{l}134 \\
294 \\
\chi_{\text {HET }}^{2}(2)=10.44 \\
p=0.005\end{array}$ & $3 \cdot 15$ \\
\hline
\end{tabular}

Table 4 Relative risks for lung cancer in professional drivers in general and in truck drivers after stratification according to age

\begin{tabular}{llllc}
\hline $\begin{array}{l}\text { Age at diagnosis } \\
\text { (years) }\end{array}$ & & Non-drivers & Drivers & Truck. drivers \\
\hline & Cases & 259 & 40 & 22 \\
$<70$ & Referents & 510 & 79 & 52 \\
& R'R & $(1 \cdot 0)$ & $1 \cdot 00$ & $0 \cdot 83$ \\
& $95 \%$ Conf interval & & $0 \cdot 66-1 \cdot 50$ & $0 \cdot 50-1 \cdot 40$ \\
& Cases & 134 & 23 & 13 \\
& Referents & 294 & 16 & 5 \\
& RR & $(1 \cdot 0)$ & $3 \cdot 15$ & $5 \cdot 70$ \\
& $95 \%$ Conf interval & & $1 \cdot 66-6.00$ & $2 \cdot 22-14 \cdot 67$ \\
\hline
\end{tabular}

The main histopathological types of lung cancer were distributed among the drivers in approximately the same way as in the total material (squamous cell carcinoma $51 \%$ and $49 \%$, small cell carcinoma $21 \%$ and $26 \%$, adenocarcinoma $14 \%$ and $13 \%$, respectively). Table 2 shows the odds ratios (OR) for professional drivers in general and for truck drivers without adjustment for age. An OR of 1.3-1.7 was obtained depending on which subgroup was studied.

The exposure, classified as professional driving, was not constant across the age strata (table 3). A heterogeneity of the odds ratio was found ( $p=$ 0.005 ) when the material was stratified into three age groups (table 3 ). The mean age of drivers was significantly lower $(p<0.0001)$ than the mean age of non-drivers in both cases and referents. Owing to these differences in age distribution in exposed and non-exposed groups, the analyses were performed for two age classes, under 70 and 70 and over. The drivers in the higher age group seemed to run an increased relative risk of lung cancer; no such tendency was observed in the lower age group (table 4). 


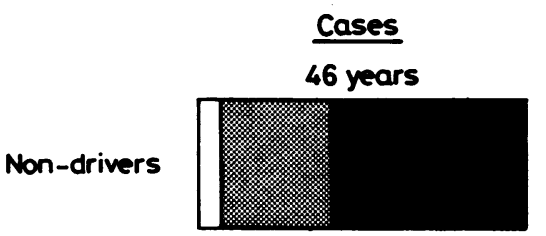

$294 \cdot 10^{3}$
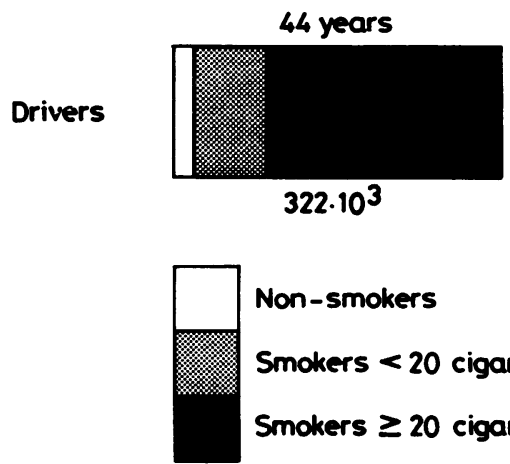

Non-smokers
Deceased referents

40 years

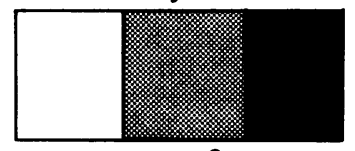

$152 \cdot 10^{3}$

38 years

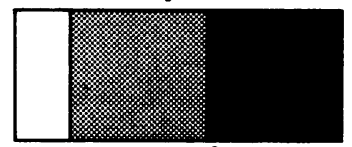

$197.10^{3}$

Cigarettes
Living referents

39 years

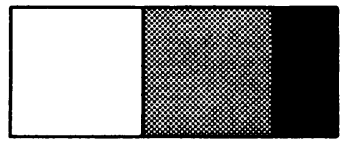

$119 \cdot 10^{3}$

37 years

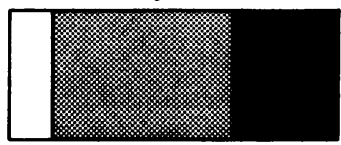

$162 \cdot 10^{3}$

Smokers $<20$ cigarettes a day

Smokers $\geq 20$ cigarettes a day

Smoking habits among cases and referents. Numbers above each rectangle represent mean smoking time; numbers below, lifetime tobacco consumption.

The average period from employment in professional driving until the diagnosis of lung cancer (the latency time) was 30 years for those aged under 70 and 45 years for those aged 70 and over. The drivers among the cases, however, had approximately the same average duration of employment (about 20 years) in the two age groups.

\section{SMOKING}

Drivers and non-drivers had different smoking habits. The drivers included relatively more smokers than the non-drivers both in the group of cases and in the two referent groups (figure). Furthermore, drivers who smoked were more often high tobacco consumers. Nevertheless, the drivers had fewer mean smoking years than the non-drivers. This could be explained by the lower mean age of the drivers. Despite the shorter smoking time, the drivers in all groups had a larger average life time consumption of tobacco than the non-drivers. The rela- tive frequency of ex-smokers was about the same in both drivers and non-drivers. Smoking drivers showed an odds ratio of the same size as smoking non-drivers when age was not taken into consideration (table 5). A slightly increased odds ratio was obtained for non-smoking drivers, but it was not significant. Stratification according to age, however, showed that the estimated relative risk for smoking drivers in the group aged 70 or over was much higher than for smoking non-drivers in the same age group (table 6). The relative risk in non-smoking drivers could not be calculated because of the lack of cases in the upper age group. Stratification according to daily tobacco consumption showed that the heavy consumers aged 70 and over had a high estimated relative risk of lung cancer (table 7). Similar analyses as in tables 6 and 7 were also performed for all cases and their deceased referents in the upper age group (including people born before 1900). This gave similar results in principle but the increase in

Table 5 Odds ratios after stratification for smoking and without adjustment to age

\begin{tabular}{|c|c|c|c|c|c|c|}
\hline & \multicolumn{2}{|l|}{ Non-drivers } & \multicolumn{2}{|c|}{ Drivers in general } & \multicolumn{2}{|l|}{ Truck drivers } \\
\hline & Non-smokers & Smokers & Non-smokers & Smokers & Non-smokers & Smokers \\
\hline $\begin{array}{l}\text { Cases } \\
\text { Referents } \\
\text { Odds ratio } \\
95 \% \text { Conf interval }\end{array}$ & $\begin{array}{c}28 \\
301 \\
(1 \cdot 0)\end{array}$ & $\begin{array}{l}365 \\
503 \\
\quad 7 \cdot 8 \\
5 \cdot 4-11 \cdot 2\end{array}$ & $\begin{array}{l}4 \\
15 \\
2 \cdot 9 \\
0 \cdot 6-9 \cdot 8^{*}\end{array}$ & $\begin{array}{l}59 \\
80 \\
7 \cdot 9 \\
5 \cdot 0-12 \cdot 7\end{array}$ & $\begin{array}{l}3 \\
6 \\
5 \cdot 4 \\
0 \cdot 8-26 \cdot 6^{*}\end{array}$ & $\begin{array}{l}32 \\
51 \\
6 \cdot 8 \\
3 \cdot 9-11 \cdot 6\end{array}$ \\
\hline
\end{tabular}

${ }^{*}$ Based on Fischer's exact test. 
Table 6 Relative risks after stratification according to smoking and age at diagnosis. All risks estimated relative to non-smokers, non-drivers in the respective age group

\begin{tabular}{|c|c|c|c|c|}
\hline & Non-smoking non-drivers & Smoking non-drivers & Smoking drivers & Smoking truck drivers \\
\hline $\begin{array}{l}\text { Age at diagnosis }<70 \\
\text { RR } \\
95 \% \text { Conf interval } \\
\text { Age at diagnosis } \geqslant 70 \\
\text { RR } \\
95 \% \text { Conf interval }\end{array}$ & $\begin{array}{cc}\mathrm{C} & 17 \\
\mathrm{R} & 191 \\
& (1 \cdot 0) \\
\mathrm{C} & 11 \\
\mathrm{R} & 110 \\
& (1 \cdot 0)\end{array}$ & $\begin{array}{l}242 \\
319 \\
8 \cdot 5 \\
6 \cdot 7-10 \cdot 9 \\
123 \\
184 \\
6 \cdot 7 \\
3 \cdot 7-12 \cdot 2\end{array}$ & $\begin{array}{l}36 \\
70 \\
5 \cdot 8 \\
3 \cdot 2-10 \cdot 5 \\
23 \\
10 \\
23 \cdot 0 \\
10 \cdot 0-52 \cdot 7\end{array}$ & $\begin{array}{l}19 \\
48 \\
4 \cdot 5 \\
2 \cdot 2-8 \cdot 9 \\
13 \\
3 \\
43 \cdot 3 \\
15 \cdot 3-122 \cdot 5\end{array}$ \\
\hline
\end{tabular}

Table 7 Relative risks for lung cancer after stratification for smoking habits and age. Risks estimated in relation to non-smokers, non-drivers

\begin{tabular}{|c|c|c|c|c|c|c|}
\hline & & \multirow{2}{*}{$\frac{\text { Non-smokers }}{\text { Non-drivers }}$} & \multicolumn{2}{|c|}{ Smokers $<20$ cig/day } & \multicolumn{2}{|c|}{ Smokers $\geqslant 20$ cig/day } \\
\hline & & & Non-drivers & Drivers & Non-drivers & Drivers \\
\hline $\begin{array}{l}\text { Age at diagnosis }<70 \\
\text { RR } \\
95 \% \text { Conf interval } \\
\text { Age at diagnosis } \geqslant 70 \\
\text { RR } \\
95 \% \text { Conf interval }\end{array}$ & $\begin{array}{l}\text { C } \\
\text { R }\end{array}$ & $\begin{array}{c}11 \\
110 \\
(1 \cdot 0)\end{array}$ & $\begin{array}{l}79 \\
195 \\
4 \cdot 6 \\
2 \cdot 7-7 \cdot 7 \\
55 \\
111 \\
5 \cdot 0 \\
2 \cdot 6-9 \cdot 6\end{array}$ & $\begin{array}{l}10 \\
37 \\
3 \cdot 0 \\
1 \cdot 3-6 \cdot 9 \\
4 \\
8 \\
5 \cdot 0 \\
1 \cdot 4-17 \cdot 5\end{array}$ & $\begin{array}{l}163 \\
125 \\
14 \cdot 7 \\
9 \cdot 1-23 \cdot 6 \\
68 \\
72 \\
9 \cdot 4 \\
5 \cdot 0-17 \cdot 9\end{array}$ & $\begin{array}{l}26 \\
33 \\
8 \cdot 9 \\
4 \cdot 6-16 \cdot 9 \\
19 \\
2 \\
95 \cdot 0 \\
32 \cdot 9-274 \cdot 8\end{array}$ \\
\hline
\end{tabular}

Table 8 Relative risks after stratification according to smoking for cases and deceased referents in the higher age group (70 or over)

\begin{tabular}{|c|c|c|c|c|c|}
\hline & & $\begin{array}{l}\text { Non-drivers } \\
\text { Non-smokers }\end{array}$ & $\begin{array}{l}\text { Non-drivers } \\
\text { Smokers }\end{array}$ & $\begin{array}{l}\text { Drivers } \\
\text { Smokers }\end{array}$ & $\begin{array}{l}\text { Truck drivers } \\
\text { Smokers }\end{array}$ \\
\hline $\begin{array}{l}\text { Age at diagnosis } \geqslant 70 \\
\text { RR } \\
95 \% \text { Conf interval }\end{array}$ & $\begin{array}{l}\mathbf{C} \\
\mathbf{R}\end{array}$ & $\begin{array}{c}25 \\
119 \\
(1 \cdot 0)\end{array}$ & $\begin{array}{l}232 \\
152 \\
7 \cdot 3 \\
4 \cdot 7-11 \cdot 3\end{array}$ & $\begin{array}{l}32 \\
10 \\
15 \cdot 2 \\
7 \cdot 3-31 \cdot 8\end{array}$ & $\begin{array}{l}16 \\
3 \\
25 \cdot 4 \\
9 \cdot 3-69 \cdot 5\end{array}$ \\
\hline
\end{tabular}

Table 9 Relative risks after stratification according to tobacco consumption for cases and deceased referents in the higher age group (70 or over)

\begin{tabular}{|c|c|c|c|c|c|c|}
\hline & & \multirow{2}{*}{$\begin{array}{l}\text { Non-smoking } \\
\text { Non-drivers }\end{array}$} & \multicolumn{2}{|c|}{ Smokers $<20$ cig/day } & \multicolumn{2}{|c|}{ Smokers $\geqslant 20$ cig/day } \\
\hline & & & Non-drivers & Drivers & Non-drivers & Drivers \\
\hline $\begin{array}{l}\text { Age at diagnosis } \geqslant 70 \\
\text { RR } \\
\text { 95\% Conf interval }\end{array}$ & $\begin{array}{l}\mathbf{C} \\
\mathbf{R}\end{array}$ & $\begin{array}{c}25 \\
119 \\
(1 \cdot 0)\end{array}$ & $\begin{array}{l}107 \\
86 \\
5 \cdot 9 \\
3 \cdot 6-9 \cdot 7\end{array}$ & $\begin{array}{l}10 \\
5 \\
9 \cdot 5 \\
3 \cdot 5-26 \cdot 1\end{array}$ & $\begin{array}{l}125 \\
66 \\
9 \cdot 0 \\
5 \cdot 5-14 \cdot 8\end{array}$ & $\begin{array}{l}22 \\
5 \\
20 \cdot 9 \\
8 \cdot 8-50 \cdot 2\end{array}$ \\
\hline
\end{tabular}

Table 10 Relative risks after stratification according to smoking and age. Ex-smokers for 10 years or more classified as non-smokers

\begin{tabular}{|c|c|c|c|c|}
\hline \multirow{2}{*}{$\begin{array}{l}\text { Age at diagnosis } \\
\text { (years) }\end{array}$} & \multicolumn{2}{|l|}{ Non-drivers } & \multicolumn{2}{|l|}{ Drivers } \\
\hline & Non-smokers* & Smokers & Non-smokers* & Smokers \\
\hline $\begin{array}{l}<70 \\
\geqslant 70\end{array}$ & $\begin{array}{l}(1.0) \\
(1.0)\end{array}$ & $\begin{array}{l}8 \cdot 6 \\
5 \cdot 8-12 \cdot 6 \\
7 \cdot 8 \\
4 \cdot 9-12 \cdot 6\end{array}$ & $\begin{array}{l}1 \cdot 9 \\
0 \cdot 5-5 \cdot 5 \dagger \\
4 \cdot 5 \\
1 \cdot 1-16 \cdot 4 \dagger\end{array}$ & $\begin{array}{l}6 \cdot 0 \\
3 \cdot 5-10 \cdot 3 \\
20 \cdot 8 \\
9 \cdot 4-46 \cdot 0\end{array}$ \\
\hline
\end{tabular}

${ }^{*}$ Includes ex-smokers (10 years or more).

†Based on Fischer's exact test. 
the relative risk in smoking drivers was less pronounced (tables 8 and 9).

A reclassification of ex-smokers of at least 10 years standing to non-smokers did not change the large relative risk estimated for smoking drivers in the high age group (table 10). Owing to the increased number of non-smoking drivers, a relative risk for this category could now be estimated. The obtained values suggested a moderately increased risk (but statistically uncertain) for this category also.

\section{Discussion}

In this study professional drivers had a considerably higher average tobacco consumption than nondrivers, which could explain the increased crude risk of lung cancer. This observation indicates the importance of a careful examination of smoking habits when occupational lung cancer risks are studied, especially when low odds ratios are found.

A difference between the relative risk for younger (under 70) and older (70 and over) professional drivers was observed, and may have several explanations. Firstly, the occupation may give an increased risk only after long exposure and the probability of such exposure will tend to be lower in the younger group. The average employment time, however, was about the same in both groups ( 20 years). Secondly, professional driving has become more frequent during the past decades, consequently, the risk in the younger group may have been underestimated owing to short observation times. This latter explanation is supported by the finding that the average latency time (from start of employment to diagnosis of lung cancer) was much longer in the older than in the younger group. Thirdly, difference in occupation exposure may have been due to car constructions and fuel composition.

Smoking drivers in the group aged 70 and over seemed to have a considerably increased risk compared with smoking non-drivers in the same age group. Numerically, a synergism was found between occupational exposure and smoking with a synergism index of 2.42 if the material with two referents was used and of 1.73 if the whole material with one referent was used. The estimated relative risks obtained when the whole material was analysed (tables 8 and 9) were lower than when only the cases with two referents were used (tables 6 and 7). The reason is probably the different composition of the referent groups. The studied exposures (smoking and occupation) may cause an additional risk concerning causes of deaths other than lung cancer. Comparison with deceased referents may therefore underestimate the lung cancer risk. The opposite may occur when living referents are used as these may represent a positively selected group concerning disease risk. The analyses with two referents (one deceased and one living) might therefore have given the best estimates.

The study suggests a synergistic interaction between smoking and occupational exposure. Unfortunately, individual smoking habits have rarely been surveyed in studies that have examined the effect of air pollution on the incidence of lung cancer. One analytical epidemiological study mentioned previously, however, in which individual smoking data were taken into account, did suggest a synergistic interaction between air pollution and smoking. ${ }^{5}$ In non-smoking drivers in the upper age group in our study an increased relative risk was also found. It was statistically uncertain but might nevertheless represent a real risk caused by occupational exposure.

This study was supported by the Swedish Cancer Society and the Swedish Work Environment Fund. We thank Ms Monica Johansson and Ms Ulla Jonsson for skilful help with the questionnaires and the preparation of this report and Mr Claes Olsson for his valuable help with the telephone interviews.

\section{References}

' Holmberg B, Ahlborg U, eds. Consensus report: mutagenicity and carcinogenicity of car exhausts and coal combustion emissions. Environ Health Perspect 1983;47:1-30.

${ }^{2}$ Doll R, Vessey MP, Beasley RWR, et al. Mortality of gasworkers-final report of a prospective study. $\mathrm{Br} \mathrm{J}$ Ind Med 1972;29:394-406.

${ }^{3}$ Hammond EC, Selikoff IJ, Lawther PL, Seidman H. Inhalation of benzopyrene and cancer in man. Ann NY Acad Sci 1976;271:116-24.

4 Lloyd JW. Long-term mortality study of steel workers. V. Respiratory cancer in coke plant workers. J Occup Med 1971;13:53-68.

sena JE. Air pollution as a risk factor in lung cancer. Am J Epidemiol 1982;116:42-56.

- Hammond EC, Garfinkel L. General air pollution and cancer in the United States. Prev Med 1980;9:206-11.

' Cederlöf R, Doll R, Fowler L, Friberg L, Nelson N, Vouk V, eds. Air pollution and cancer: risk assessment methodology and epidemiological evidence. Report of a task group. Environ Health Perspect 1978;22:1-10.

${ }^{*}$ Schenker MB. Diesel exhaust-an occupational carcinogen? J Occup Med 1980;22:41-6.

- Springer KJ, Bains TM. Emission from diesel versions of production passenger cars. Society of Automotive Engineers, Passenger Car Meeting, Detroit, Michigan, 26-30 September 1977. (Quoted in Schenker MB.")

${ }^{10}$ Depue RH, Menck HR. Registry data as an "alert" system for detection of occupational lung cancer risk. $J$ Natl Cancer Inst 1980;65:495-6.

" Enterline PE. McKiever MF. Differential mortality from lung cancer by occupation. J Occup Med 1963;5:283-90.

12 Menck HR, Henderson BE. Occupational differences in rates of cancer. J Occup Med 1976; 18:797-801. 
${ }^{13}$ Occupational mortality 1970-1973. Oslo: Central Bureau of Statistics of Norway, 1976

14 Wachsmuth N, Viereck HJ. Beitrag zur Ätiologie des Bronchial-karzinoms. Dtsch Med Wochenschr 1964;89:60611.

is Raffle PAB. The health of the worker. Br J Ind Med 1957; 14:73-80.

16 Waller RE. Trends in lung cancer in London in relation to exposure to diesel fumes. In: Pepelko WE, Danner RM. Clarke NA, eds. Health effects of diesel engine emissions. Washington: US Environmental Protection Agency, 1980: 1085-97.

17 Ahlberg J, Ahlbom A, Lipping H, Norell S, Österblom L. Cancer in professional drivers: a problem oriented register study. Läkartidningen 1981;78:1545-6. (In Swedish.)

${ }^{18}$ Gustavsson L, Skog B, Wall S. Death cause pattern and cancer incidence among Swedish stevedores. Solna; Transporthälsan, 1983. (In Swedish.)

${ }^{14}$ Damber L, Larsson LG. Combined effects of mining and smoking in the causation of lung carcinoma. A case-control study in northern Sweden. Acta Radiol Oncol 1982;21:305-13.

${ }^{20}$ Larsson LG, Damber L. Interaction between underground mining and smoking in the causation of lung cancer: a study of non-uranium miners in northern Sweden. Cancer Detect Prev 1982;5:385-9.

${ }^{21}$ Smulevich VB, Bulbulian MA. Quantitative assessment of environmental pollution by cancerogenic substances: one stage in the epidemiological study of tumours. Int J Epidemiol 1974; 3:321-3.

${ }^{22}$ Miettinen O. Estimation of relative risk from individually matched series. Biometrics 1970;26:75-86.

${ }^{23}$ Miettinen O. Estimability and estimation in case-referent studies. Am J Epidemiol 1976; 103:226-35.

${ }^{24}$ Gart JJ. The comparison of proportion: a review of significance tests, confidence intervals and adjustments for stratification. Review of the International Statistical Institute 1971;39:14869.

${ }^{25}$ Rothman KJ. Synergy and antagonism in cause-effect relationships. Am J Epidemiol 1974;99:385-8. 